\title{
The Combination of Functional Metagenomics and an Oil-Fed Enrichment Strategy Revealed the Phylogenetic Diversity of Lipolytic Bacteria Overlooked by the Cultivation-Based Method
}

\author{
TAKASHI NARIHIRO ${ }^{1,2 *}$, AYA SUZUKI ${ }^{1,3 *}$, KAZUAKI YOSHIMUNE ${ }^{1 \dagger}$, TOMOYUKI HORI ${ }^{1}$, TAMOTSU HOSHINO ${ }^{1}$, ISAO YUMOTO ${ }^{1,3}$, \\ ATSUSHI YOKOTA ${ }^{4}$, NOBUTADA KIMURA ${ }^{2}$, and YoICHI KAMAGATA ${ }^{1,2,3,4}$ \\ ${ }^{1}$ Bioproduction Research Institute, National Institute of Advanced Industrial Science and Technology (AIST), 2-17-2-1 \\ Tsukisamu-Higashi, Toyohiraku, Sapporo, Hokkaido 062-8517, Japan; ${ }^{2}$ Bioproduction Research Institute, National Institute \\ of Advanced Industrial Science and Technology (AIST), Higashi 1-1-1, Tsukuba, Ibaraki 305-8566, Japan; ${ }^{3}$ Division of Applied \\ Bioscience, Graduate school of Agriculture, Hokkaido University, Kita 9 Nishi 9, Kita-ku, Sapporo, Hokkaido 060-8589, Japan; \\ and ${ }^{4}$ Division of Applied Bioscience, Research Faculty of Agriculture, Hokkaido University, Kita 9 Nishi 9, Kita-ku, Sapporo, \\ Hokkaido, 060-8589, Japan
}

(Received January 7, 2014_Accepted March 8, 2014_Published online May 23, 2014)

Metagenomic screening and conventional cultivation have been used to exploit microbial lipolytic enzymes in nature. We used an indigenous forest soil (NS) and oil-fed enriched soil (OS) as microbial and genetic resources. Thirty-four strains (17 each) of lipolytic bacteria were isolated from the NS and OS microcosms. These isolates were classified into the (sub)phyla Betaproteobacteria, Gammaproteobacteria, Firmicutes, and Actinobacteria, all of which are known to be the main microbial resources of commercially available lipolytic enzymes. Seven and 39 lipolytic enzymes were successfully retrieved from the metagenomic libraries of the NS and OS microcosms, respectively. The screening efficiency (a ratio of positive lipolytic clones to the total number of environmental clones) was markedly higher in the OS microcosm than in the NS microcosm. Moreover, metagenomic clones encoding the lipolytic enzymes associated with Alphaproteobacteria, Deltaproteobacteria, Acidobacteria, Armatimonadetes, and Planctomycetes and hitherto-uncultivated microbes were recovered from these libraries. The results of the present study indicate that functional metagenomics can be effectively used to capture as yet undiscovered lipolytic enzymes that have eluded the cultivation-based method, and these combined approaches may be able to provide an overview of lipolytic organisms potentially present in nature.

Key words: functional metagenomics, cultivation, lipolytic enzymes, uncultured microbes

Lipolytic enzymes, including esterases (EC 3.1.1.1) and lipases (EC 3.1.1.3), are used in food, chemical, and pharmaceutical industries as well as waste treatment and biofuel production $(19,20,22,24)$. Commercially available bacterial lipolytic enzymes are mainly derived from culturable strains within the phyla Proteobacteria, Firmicutes, and Actinobacteria. For example, lipolytic enzymes purified from the genera Burkholderia and Pseudomonas are widely used as detergent additives and in organic synthesis $(19,22,25)$, and members of the genera Bacillus, Chromobacterium, Staphylococcus, and Streptomyces are listed as popular lipolytic enzyme-producing bacteria $(19,20,24)$. The cultivation-based screening method has been employed as one of the main strategies to obtain such microbial resources of not only lipolytic enzymes, but also other biocatalysts from microbial ecosystems $(42,52)$. However, significant proportions of microorganisms in various environment samples (e.g., soil, sediment, sea water, fresh water, and sludge) have yet to be cultivated and remain functionally unknown $(41,44)$, which implies that there is room for the

\footnotetext{
* Corresponding author. E-mail: t.narihiro@aist.go.jp,

Tel: +81-29-861-6591; Fax: +81-29-861-6587.

$\dagger$ Present address: Department of Applied Molecular Chemistry,

College of Industrial Technology, Nihon University, 1-2-1

Izumichou, Narashino, Chiba 275-8575, Japan

* These authors contributed equally to this work.
}

expansion of microbial resources to obtain better lipolytic enzymes produced by uncultivated microorganisms.

Functional metagenomics has recently been used to expand the availability of biocatalytic enzymes $(17,31,56)$. Since this approach allows the step of cultivation to be skipped, the genetic resources of uncultivated microorganisms in complex microbial communities may be directly accessed. To date, many studies have reported the screening of novel lipolytic enzymes from the functional metagenomic libraries of soil $(6,8,12,15,16,21,27,28,30,35,36,38,46,48,53,60,64)$, marine sediment $(23,26)$, tidal flat sediments (34), deep-sea water (18), surface seawater (9), drinking water biofilms (12), pond water (45), hot springs (47), and activated sludge (37). However, no studies have yet compared the phylogenetic diversity of genes encoding lipolytic enzymes obtained by functional metagenomics to that of culturable lipolytic strains isolated using traditional cultivation-based screening techniques.

In addition, although the functional metagenomic approach is a powerful screening tool for novel biocatalysts, a large number of metagenomic clones are generally needed to obtain gene fragments encoding target enzymes. To the best of our knowledge, the maximum screening efficiency of lipolytic enzymes (i.e., the ratio of positive lipolytic clones to total metagenomic clones) was shown to be $0.35 \%$ in a soil metagenomic library containing 34,560 fosmid clones (15); however, most attempts have reported markedly lower 
efficiencies $(<0.1 \%)(6,21,27,28,30,35,36,48,53,59)$. Therefore, a specific biocatalyst-targeted enrichment strategy was applied to improve this efficiency rate $(8,12,13,18,33$, 59). Olive oil (8), mineral oil (12), and crude oil (18) have been used as substrates for the metagenomic screening of lipolytic enzymes. In these studies, two phylogenetically novel lipolytic genes were successfully obtained from metagenomic libraries derived from olive oil-enriched soil and water samples (8). However, no comparative study has examined the frequency of positive clones and phylogenetic diversity of the screened lipolytic enzymes between enriched and non-enriched environmental samples.

In this study, we used comprehensive approaches including both functional metagenomics and a cultivation-dependent method combined with oil-fed enrichment to uncover the entire microbial resources of lipolytic enzymes. Forest soil microbial communities serve important ecological functions, including carbon, nitrogen, and phosphorous cycles, plant diversity, and soil fertility $(10,58)$. Natural (unmanaged) forest soils are considered to contain an arsenal of microbial genetic resources including lipolytic enzymes $(27,38)$. We here used natural forest soil as a representative community and employed four different procedures: (i) functional metagenomic screening from natural forest soil; (ii) cultivation-based screening from natural forest soil; (iii) functional metagenomic screening from oil-enriched soil; (iv) cultivation-based screening from oil-enriched soil.

\section{Materials and Methods}

Strains, plasmids, and growth conditions

E. coli strain EPI300 (Epicentre, Madison, WI, USA) and the Copy Control pCC1FOS vector (Epicentre) were used to construct metagenomic libraries. The growth conditions of $E$. coli strains were described previously (32).

\section{Soil sample and enrichment}

Soil samples were collected in May 2007 from a forest located in Sapporo, Hokkaido, Japan $\left(43^{\circ} 04^{\prime} \mathrm{N}, 141^{\circ} 30^{\prime} \mathrm{E}\right)$. The vegetation type was a cool temperate deciduous broadleaf forest (Quercus crispula Blume, Trillium smallii, Anemone flaccida, Sasa spp., and ferns of the Dryopteridaceae were observed). Pebbles and plant roots were removed from the samples. The moisture content and $\mathrm{pH}$ of the soil samples were measured using a previously described method (40). Non-enriched soil samples (hereafter "NS") were immediately subjected to cell counting, DNA extraction, and lipolytic activity measurements. To prepare the oil-enriched soil sample (hereafter "OS"), $500 \mathrm{~g}$ (wet wt) of soil was placed into a 2-L conical glass flask with a silicon cap, and incubated at $30^{\circ} \mathrm{C}$ for 2 months without continuous aeration and shaking. A total of $2.5 \mathrm{~mL}$ of olive oil (Wako Pure Chemical Industries, Osaka, Japan) was added to the soil and mixing by a spoon every second week. The moisture content and $\mathrm{pH}$ were maintained at the initial states during the enrichment by adding distilled water and sodium bicarbonate, respectively.

\section{Lipolytic activity of soil samples}

The lipolytic activities of NS and OS were measured by copper soap colorimetry with small modifications (49). Briefly, $1 \mathrm{~g}$ (wet wt) of soil was mixed with $1.25 \mathrm{~mL}$ of $2 \%$ polyvinyl alcohol:olive oil $(3: 1, \mathrm{v} / \mathrm{v})$ emulsified solution and $1.25 \mathrm{~mL}$ of $200 \mathrm{mM}$ potassium phosphate buffer ( $\mathrm{pH} 6.5$ ). The reaction proceeded at $37^{\circ} \mathrm{C}$ for 20 min and was stopped by the addition of $5 \mathrm{~mL}$ of $200 \mathrm{mM}$ potassium phosphate buffer and $5 \mathrm{~mL}$ of acetone. After $2.5 \mathrm{~mL}$ of isooctane was added, the reaction mixture was vortexed and boiled for $1 \mathrm{~min}$. The upper isooctane phase containing free fatty acids was collected and mixed with $1 \mathrm{~mL}$ copper reagent (49). The resultant mixture was vortexed for $1.5 \mathrm{~min}$ and the absorbance of the isooctane phase was measured at $715 \mathrm{~nm}$. One unit of lipase activity was defined as $1 \mu \mathrm{M}$ free fatty acid released for $1 \mathrm{~min}$. Oleic acid was used as the standard of free fatty acids.

\section{Cell counting and isolation of major lipolytic bacteria}

In cell counting and the isolation of lipolytic bacteria, $1 \mathrm{~g}$ (wet wt) of a soil sample was sonicated and diluted serially with phosphate-buffered saline (PBS), as described previously (39). Direct total counts of bacteria were measured by the epifluorescence microscopic method described by Yoshida et al. (63). Plate counts of culturable lipolytic bacteria were performed using tributyrin agar plates: per L, $5 \mathrm{~g}\left(\mathrm{NH}_{4}\right)_{2} \mathrm{SO}_{4} ; 1 \mathrm{~g} \mathrm{KH}_{2} \mathrm{PO}_{4} ; 1 \mathrm{~g} \mathrm{~K}_{2} \mathrm{HPO}_{4} ; 0.1 \mathrm{~g}$ $\mathrm{MgSO}_{4} 7 \mathrm{H}_{2} \mathrm{O} ; 5$ g tributyrin; $1 \mathrm{~g}$ arabic gum ( $\mathrm{pH} 7.0$ by NaOH). We initially attempted to prepare the olive oil-containing agar plate for the isolation of lipolytic bacteria and selection of the E. coli transformant; however, it was difficult to prepare a homogeneously diffused olive oil agar plate. Due to this obstacle, a tributyrincontaining agar plate was used for the isolation of lipolytic bacteria from NS and OS samples (and also for the selection of the E. coli transformant as described below). The inoculated plates were incubated at $30^{\circ} \mathrm{C}$ for 2 months before counting colony-forming units (CFU). In order to isolate the main lipolytic bacteria in NS and OS communities, single halo-forming colonies were picked up randomly from the "countable plates," which were inoculated with 100 $\mu \mathrm{L}$ of $10^{-3}-10^{-4}$ diluted samples and contained 3-10 colonies with clear single halos, and subjected to a standard purification procedure with the repeated streaking of tributyrin agar plates. Phylogenetic analysis of the isolates was performed by partial ( $c a .500 \mathrm{bp}$ ) $16 \mathrm{~S}$ rRNA gene sequencing according to a previously described method (40).

\section{Metagenomic screening of the lipolytic fosmid clone}

DNA extraction, purification, manipulation, and metagenomic library construction were performed using the methods described by Kimura et al. (32). To select lipolytic clones from the constructed fosmid libraries, metagenomic clones in E. coli EPI300 were cultured on LB agar supplemented with $12.5 \mu \mathrm{g} \mathrm{mL}{ }^{-1}$ chloramphenicol for $3 \mathrm{~d}$ at $37^{\circ} \mathrm{C}$. The number of clones per plate was adjusted to approximately 1,000 by the dilution of library stocks, and the plates were incubated overnight at $37^{\circ} \mathrm{C}$ and stored as a "master plate". The colonies growing on the master plates were replicated on a LB agar plate supplemented with $0.5 \%$ tributyrin, $0.1 \%$ arabic gum, and chloramphenicol (7). The replicated plates were incubated for $3 \mathrm{~d}$ at $37^{\circ} \mathrm{C}$, and the metagenomic clones that produced single halos were isolated. The average insert sizes of cloned lipolytic DNA were estimated by $\mathrm{Bam} \mathrm{H} 1$ digested fragment analyses of 16 randomly selected clones (32).

\section{In vitro mutagenesis and sequencing of metagenomic clones}

In vitro mutagenesis of the selected lipolytic clones was performed by using the EZ::TN KAN-2 transposon kit (Epicentre) according to a previously described method (32). Briefly, positive $E$. coli EPI300 cells were incubated in $10 \mathrm{~mL}$ LB broth supplemented with $12.5 \mu \mathrm{g} \mathrm{mL}-1$ chloramphenicol at $37^{\circ} \mathrm{C}$ for $16 \mathrm{~h}$. After incubation, the cells were collected by centrifugation $\left(6,300 \times g\right.$, at $4^{\circ} \mathrm{C}$ for $5 \mathrm{~min}$ ). Fosmid DNA was purified from the cells with a QIAprep Spin Miniprep Kit (Qiagen, Hilden, Germany). Regarding transposon-based mutagenesis, $2 \mu \mathrm{L}$ fosmid DNA (100 ng $\left.\mu \mathrm{L}^{-1}\right)$ was mixed with $2 \mu \mathrm{L}$ EZ-Tn5 Transposon containing a kanamycinresistant gene $\left(0.002 \mathrm{pmol} \mu \mathrm{L}^{-1}\right), 0.5 \mu \mathrm{L} 10 \times$ Reaction Buffer, and $0.5 \mu \mathrm{L}$ EZ-Tn5 Transposase $\left(1 \mathrm{U} \mu \mathrm{L}^{-1}\right)$, and then incubated at $37^{\circ} \mathrm{C}$ for $2 \mathrm{~h}$. The reaction was stopped by adding $1 \mu \mathrm{L} 10 \times$ Stop Solution, and incubated at $60^{\circ} \mathrm{C}$ for $10 \mathrm{~min}$. The mutated fosmid DNA was mixed with E. coli EPI300 cells in 0.2 cm-gap Gene Pulser/ MicroPulser Cuvettes (Bio-Rad, Hercules, CA, USA), and electro- 
porated at $2.0 \mathrm{kV}$ with a Gene Pulser (Bio-Rad). After electroporation, the cells were suspended in $815 \mu \mathrm{L}$ of $\mathrm{LB}$ broth and allowed to grow at $37^{\circ} \mathrm{C}$ for $1 \mathrm{~h}$. A portion of the cell suspension ( $c a$. $100 \mu \mathrm{L}$ ) was cultured on the LB agar plate supplemented with 12.5 $\mu \mathrm{g} \mathrm{mL}{ }^{-1}$ chloramphenicol and $50 \mu \mathrm{g} \mathrm{mL}^{-1}$ kanamycin at $37^{\circ} \mathrm{C}$ for $1 \mathrm{~d}$. The colonies growing on the plates were replicated on the LB agar plate supplemented with $0.5 \%$ tributyrin, $0.1 \%$ arabic gum, $12.5 \mu \mathrm{g} \mathrm{mL}^{-1}$ chloramphenicol, and $50 \mu \mathrm{g} \mathrm{mL}^{-1}$ kanamycin. E. coli transformants without clear halos represented on LB-tributyrin plate were isolated, and fosmid DNA was purified with a QIAprep Spin Miniprep Kit (Qiagen). The transposon insertion sites were sequenced with the primers KAN-2 FR-1 and RP-1 (Epicentre), a BigDye Terminator v3.1 Cycle Sequencing Kit (Applied Biosystems, Carlsbad, CA, USA), and a 3130xl Genetic Analyzer (Applied Biosystems). DNA sequences were analyzed with BLAST and ORF finder programs provided by the National Center for Biotechnology Information (51). The alignment of the translated amino acid sequences and construction of a distance matrix tree on the basis of the neighbor-joining method (50) were performed with the MEGA software (55). According to previous studies on the phylogeny of lipolytic enzymes, the phylogenetic affiliations of the lipolytic enzymes were relatively consistent with the $16 \mathrm{~S}$ rRNAbased phylogeny $(2,8,24,27,38)$. Therefore, we compared the phylogenetic diversity of lipolytic bacteria based on the 16S rRNA gene sequences of the culturable isolates and amino acid sequences of the metagenomic clones.

Nucleotide sequence accession numbers

The nucleotide sequences of the lipolytic enzyme genes and 16S rRNA genes presented in this study have been deposited under DDBJ/EMBL/GenBank accession numbers AB811356 to AB811435.

\section{Results}

Effect of the oil-fed enrichment strategy on cell counting and soil lipase activity

The moisture content and $\mathrm{pH}$ of NS was 7.1 and $60 \%$, respectively. During the enrichment period, moisture content and $\mathrm{pH}$ values were maintained at levels of 6.57.5 and $55-65 \%$, respectively. The plate counts of lipolytic bacteria in NS and OS accounted for $0.031 \%$ and $0.57 \%$ of the direct total counts, respectively, indicating that the number of lipolytic bacteria was 18 -fold higher in the OS microcosm than in NS microcosm (Table 1). Soil lipolytic activity also increased 4.6-fold after the oil-fed enrichment strategy (Table 1), which demonstrated that lipolytic microorganisms were enriched in the OS microcosm. The bacterial community structures of NS and OS were analyzed by 16S rRNA gene cloning (see Supplemental information). The results obtained showed that the clonal sequences of both microcosms were assigned to eight bacterial phyla (i.e., Proteobacteria, Actinobacteria, Acidobacteria, Bacteroidetes, Verrucomicrobia, Planctomycetes, Chloroflexi, and Nitrospirae) and hitherto-uncultured bacterial groups (i.e., candidate phyla SPAM and WS3) (Table S1). The Chaol diversity index based on phylotypes having $>97 \%$ nucleotide sequence identity was reduced to one-quarter after the oil-fed enrichment.

\section{Phylogenetic affiliations of culturable lipolytic isolates}

We isolated the respective 17 strains from the tributyrin agar plates used for plate counting of lipolytic bacteria in the NS and OS samples, and these were identified by partial $16 \mathrm{~S}$
Table 1. Cell counting, lipase activity, and metagenomic library of non-enriched soil (NS) and oil-enriched soil (OS)

\begin{tabular}{|c|c|c|}
\hline Properties & NS & OS \\
\hline Total cells $\left(\times 10^{9} \text { cell g }^{-1}[\text { dry wt }]\right)^{\mathrm{a}}$ & $5.3 \pm 1.2$ & $2.4 \pm 0.1$ \\
\hline $\begin{array}{l}\text { Culturable lipolytic bacteria } \\
\left(\times 10^{6} \mathrm{CFU} \mathrm{g^{-1 }} \text { [dry wt }\right)^{\mathrm{a}}\end{array}$ & $1.7 \pm 0.2$ & $13.8+2.5$ \\
\hline $\begin{array}{l}\text { The ratio of culturable lipolytic bacteria } \\
\text { to the total number of cells }(\%)\end{array}$ & 0.031 & 0.57 \\
\hline Soil lipase activity $\left(\mathrm{U} \mathrm{g}^{-1}[\text { dry wt }]\right)^{\mathrm{a}}$ & $55.3+7.3$ & $252.8+37.7$ \\
\hline \multicolumn{3}{|l|}{ Metagenomic libraries } \\
\hline Total number of clones & 80,000 & 130,000 \\
\hline Average insert size $(\mathrm{kb})$ & 28.6 & 28.1 \\
\hline Estimated total amount of DNA $(\mathrm{Gb})$ & 2.29 & 3.65 \\
\hline Positive lipolytic clones & 7 & 49 \\
\hline $\begin{array}{l}\text { The ratio of positive lipolytic clones to } \\
\text { the total number of clones }(\%)\end{array}$ & 0.00875 & 0.0377 \\
\hline
\end{tabular}

a Averages and standard deviations were calculated based on 10,5, and 2 replicates for the total number of cells, culturable lipolytic bacteria, and soil lipase activity, respectively.

rRNA gene sequencing (Table 2). All of the isolates were identified as members of the (sub)phyla Betaproteobacteria, Gammaproteobacteria, Firmicutes, and Actinobacteria. The majority of genera to which the isolates from the NS were assigned were associated with Bacillus (7 out of 17 strains), Lysinibacillus (4 out of 17 strains), and Pseudomonas (4 out of 17 strains), and those associated with the genera Burkholderia (1 out of 17 strains) and Rhodococcus (1 out of 17 strains) were found to be minor constituents. After the enrichment procedure, the lipolytic bacteria assigned to the genera Burkholderia (12 out of 17 strains) and Bacillus ( 3 out of 17 strains) dominated in the OS microcosm, except for one strain of Mitsuaria (1 out of 17 strains) and one strain of Curtobacterium (1 out of 17 strains) (Table 2). These results indicated that the oil-fed enrichment strategy selected particular lipolytic bacteria and excluded other indigenous culturable lipolytic bacteria.

\section{Screening of lipolytic clones from the metagenomic library}

Two fosmid libraries were constructed from the total genomic DNA extracted from NS and OS. The average insert sizes of lipolytic clones obtained from NS and OS were estimated to be 28.1 and $28.6 \mathrm{kbp}$, amounting to approximately 2.3 and $3.7 \mathrm{Gbp}$, respectively (Table 1 ). Among the clones retrieved from NS and OS, 7 and 49 clones showed a clear halo on the LB-tributyrin agar plate. A 4.3-fold increase was observed in the frequency (a ratio of positive lipolytic clones to the total number of clones) after the oil-fed enrichment procedure, suggesting that the oil-fed enrichment strategy was effective at capturing lipolytic metagenomic clones. A total of 56 clones were subjected to subcloning and screening for lipolytic activity in the secondary libraries. All of the 7 clones retrieved from NS were successfully subcloned and sequenced. Of the 49 clones from the OS microcosm library, 39 fosmid clones whose lipolytic activity was confirmed were successfully obtained (Table 3 ).

\section{Phylogenetic affiliations of lipolytic enzymes from metagenomic clones}

The deduced amino acid sequences of all lipolytic enzymes from the NS and OS metagenomic libraries had high identities with those of the conserved domains of $\alpha / \beta$ hydrolase, 
Table 2. Phylogenetic identification of the lipolytic bacteria isolated from original soil (NS) and oil-enriched soil (OS)

\begin{tabular}{|c|c|c|c|c|}
\hline \multirow{2}{*}{ Phylogeny assigned } & \multirow{2}{*}{$\begin{array}{l}\text { No. of strains } \\
\text { isolated }\end{array}$} & \multicolumn{3}{|c|}{ 16S rRNA gene sequence comparison } \\
\hline & & Species as closest relatives & Accession no. & Identity (\%) \\
\hline \multicolumn{5}{|l|}{ NS (non-enriched soil) } \\
\hline \multicolumn{5}{|l|}{ Phylum Firmicutes } \\
\hline \multirow[t]{3}{*}{ Bacillus } & 4 & Bacillus simplex DSM 1321 & NR_042136 & $99.6-100$ \\
\hline & 2 & Bacillus megaterium NBRC 13498 & $\mathrm{AB} \overline{6} 80420$ & $99.7-100$ \\
\hline & 1 & Bacillus thuringiensis serovar kurstaki HD73 & СР004069 & 99.9 \\
\hline Lysinibacillus & 4 & Lysinibacillus sphaericus $205 \mathrm{y}$ & AF435435 & $99.7-100$ \\
\hline \multicolumn{5}{|l|}{ Phylum Proteobacteria } \\
\hline \multicolumn{5}{|l|}{ Class Betaproteobacteria } \\
\hline \multicolumn{5}{|l|}{ Class Gammaproteobacteria } \\
\hline \multirow[t]{4}{*}{ Pseudomonas } & 1 & Pseudomonas arsenicoxydans MaBP1 & JQ317810 & 99.3 \\
\hline & 1 & Pseudomonas putida ATCC 17472 & AF094738 & 99.6 \\
\hline & 1 & Pseudomonas putida NBRC 102093 & AB681704 & 98.7 \\
\hline & 1 & Pseudomonas vancouverensis DhA-51 & AJ011507 & 99.7 \\
\hline \multicolumn{5}{|l|}{ Phylum Actinobacteria } \\
\hline Rhodococcus & 1 & Rhodococcus erythropolis CR-53 & AJ786263 & 99.4 \\
\hline \multicolumn{5}{|l|}{ OS (Oil-enriched soil) } \\
\hline \multicolumn{5}{|l|}{ Phylum Firmicutes } \\
\hline Bacillus & 2 & Bacillus thuringiensis serovar kurstaki HD73 & CP004069 & $99.5-99.8$ \\
\hline \multicolumn{5}{|l|}{ Phylum Proteobacteria. } \\
\hline \multirow{3}{*}{$\begin{array}{l}\text { Class Betaproteobacteria } \\
\text { Burkholderia }\end{array}$} & & & & \\
\hline & $\begin{array}{r}10 \\
1\end{array}$ & $\begin{array}{l}\text { Burkholderia caledonica LMG } 19076 \\
\text { Burkholderia hospita LMG } 20598\end{array}$ & $\begin{array}{l}\text { HQ849076 } \\
\text { HQ849087 }\end{array}$ & $\begin{array}{c}97.9-99.8 \\
99.1\end{array}$ \\
\hline & 1 & $\begin{array}{l}\text { Burkholderia glathei N15 } \\
\text { Mitsuaria chitosanitabida NBRC } 102408\end{array}$ & NR 037065 & 97.9 \\
\hline \multirow{2}{*}{$\begin{array}{l}\text { Mitsuaria } \\
\text { Phylum Actinobacteria } \\
\text { Curtobacterium }\end{array}$} & 1 & Mitsuarıa chitosanitabida NBRC 102408 & AB $081 / 0$ & 98 \\
\hline & 1 & Curtobacterium herbarum DSM 14013 & AM410692 & 96.0 \\
\hline
\end{tabular}

$\beta$-lactamase-type hydrolase, and lipase/esterase (Table 3). The majority of lipolytic enzymes from NS was assigned to Alphaproteobacteria, Planctomycetes, and Acidobacteria, and was associated with the families IV, V, and VIII (Fig. $\mathrm{S} 1$ ). On the other hand, those from the OS library were mainly assigned to Alphaproteobacteria, Betaproteobacteria, Gammaproteobacteria, Deltaproteobacteria, Acidobacteria, Armatimonadetes, and Actinobacteria, and were associated with the families II, IV, V, and VIII, and the feruloyl esterase group (Fig. S1). The 16S rRNA gene clones classified into these taxa were detected in both the NS and OS communities, except for the members of Armatimonadetes (Table S1).

In addition to the previously known taxa, the functional metagenomic approach enabled us to capture lipolytic enzymes associated with uncultured microorganisms (Table $3)$. The phylogenetic tree based on amino acid sequences indicated that clones NSm06 and NSm07 obtained from NS were clustered into lipase family $\mathrm{V}$, and had a similar identity to the soil-derived metagenomic clone pUlp286 (53.8\% and $50.5 \%$ amino acid identities, respectively) (Fig. 1). Within the OS library, a total of 14 clones showed the highest identities to the lipolytic enzymes of uncultured microbes (Table 3 ), and were divided into three clusters: lipase family IV, the feruloyl esterase group, and a novel cluster (Fig. 1). Twelve clones (OSm27-35 and OSm37-39) were assigned to lipase family IV, and all of these clones had significant identities (61.7\%-84.8\% amino acid identities) to the lipolytic genes obtained from soil and marine sediment samples. The OSm 36 clone had $45.1 \%$ amino acid identity with the feruloyl esterase gene of the uncultured bacterium FeKT1 obtained from the marine sediment metagenomic library. In addition, the OSm26clone showed $50.0 \%$ amino acid identity to the lipolytic gene found in the groundwater sample.

\section{Discussion}

As reported here, our comparative analyses with two screening approaches (i.e., functional metagenomics and a cultivation-based method) combined with the oil-fed enrichment strategy revealed the entire picture of the phylogenetic diversity of lipolytic bacteria in the forest soil environment, as summarized in a Venn diagram (Fig. 2). One of the most important results was that the functional metagenomic approach detected significant amounts of lipolytic enzymes associated with the phylogenetic groups that were absent in the catalogs of culturable isolates in both NS and OS microcosms; i.e., the (sub)phyla Alphaproteobacteria, Deltaproteobacteria, Acidobacteria, Armatimonadetes, and Planctomycetes. Within the class Alphaproteobacteria, 2 and 12 lipolytic enzymes were identified in NS and OS, respectively. One metagenomic clone associated with Deltaproteobacteria and Armatimonadetes was retrieved from the OS library only. Within the phylum Acidobacteria, 1 and 3 lipolytic enzymes were retrieved from NS and OS, respectively. Two lipolytic enzymes showed the highest identity to those of the phylum Planctomycetes in the NS library only. Although several lipolytic enzymes associated with Alphaproteobacteria, Deltaproteobacteria, Acidobacteria, and Planctomycetes have been identified in soil metagenomic libraries $(6,12,16,35,38)$, to the best of our knowledge, there have been no commercially available lipolytic enzymes produced by the culturable strains of these taxa $(19,22)$. Another important result in our study is that both NS and OS libraries contained a significant proportion of lipolytic enzymes associated with uncultured microorganisms. Based on the phylogenetic analysis, such lipolytic enzymes showed 
Table 3. Phylogenetic identification of the lipolytic metagenomic clones from original soil (NS) and oil-enriched soil (OS)

\begin{tabular}{|c|c|c|c|c|c|c|}
\hline Phylogeny assigned & Clone no. & Closest relatives & Accession no. & Product & Identity $(\%)$ & Family/Group ${ }^{\mathrm{a}}$ \\
\hline \multicolumn{7}{|l|}{ NS (non-enriched soil) } \\
\hline \multirow[t]{2}{*}{ Alphaproteobacteria } & $\mathrm{NSm} 01$ & Parvibaculum lavamentivorans DS-1 & YP_001411752 & $\alpha / \beta$ hydrolase & 54.3 & IV \\
\hline & $\mathrm{NSm} 02$ & Methylobacterium nodulans ORS 2060 & YP_002501216 & $\beta$-lactamase & 47.2 & VIII \\
\hline \multirow[t]{2}{*}{ Planctomycetes } & $\mathrm{NSm} 03$ & Planctomyces maris DSM 8797 & ZP_01853484 & $\alpha / \beta$ hydrolase & 52.4 & IV \\
\hline & $\mathrm{NSm04}$ & Pirellula staleyi DSM 6068 & YP_003372868 & $\alpha / \beta$ hydrolase & 39.9 & V \\
\hline Acidobacteria & $\mathrm{NSm} 05$ & $\begin{array}{l}\text { "Candidatus Solibacter usitatus" } \\
\text { Ellin6076 }\end{array}$ & YP_825272 & $\alpha / \beta$ hydrolase & 77.8 & V \\
\hline \multirow{2}{*}{ Unidentified groups } & NSm06 & uncultured bacterium clone pUlp286 & ABQ11270 & Lipase/esterase & 53.8 & V \\
\hline & NSm07 & uncultured bacterium clone pUlp286 & ABQ11270 & Lipase/esterase & 50.5 & $\mathrm{~V}$ \\
\hline \multicolumn{7}{|l|}{ OS (oil-enriched soil) } \\
\hline \multirow[t]{12}{*}{ Alphaproteobacteria } & OSm01 & Tistrella mobilis KA081020-065 & YP_006374406 & $\beta$-lactamase & 55.0 & VIII \\
\hline & OSm02 & Caulobacter sp. K31 & YP_001682441 & $\beta$-lactamase & 92.2 & VIII \\
\hline & OSm03 & $\begin{array}{l}\text { Methylobacterium radiotolerans JCM } \\
2831\end{array}$ & YP_001752969 & $\alpha / \beta$ hydrolase & 37.1 & IV \\
\hline & OSm04 & Methylobacterium nodulans ORS 2060 & YP_002498598 & $\beta$-lactamase & 58.7 & FE \\
\hline & OSm05 & Parvibaculum lavamentivorans DS-1 & YP_001411752 & $\alpha / \beta$ hydrolase & 58.5 & IV \\
\hline & OSm06 & Hyphomonas neptunium АТCC 15444 & YP_759849 & Putative esterase & 69.8 & VIII \\
\hline & OSm07 & Bradyrhizobium diazoefficiens USDA 110 & NP_770666 & $\beta$-lactamase & 86.2 & VIII \\
\hline & OSm08 & Hyphomonas neptunium ATCC 15444 & YP_759753 & Putative esterase & 58.6 & VIII \\
\hline & OSm09 & Sphingomonas echinoides ATCC 14820 & $\mathrm{ZP}_{-}{ }^{-1} 0338216$ & $\beta$-lactamase & 70.8 & VIII \\
\hline & OSm10 & Mesorhizobium opportunistum WSM2075 & ZP_05809008 & $\alpha / \beta$ hydrolase & 53.5 & V \\
\hline & OSm11 & Rhizobium tropici CIAT 899 & YP_007335702 & $\alpha / \beta$ hydrolase & 50.0 & IV \\
\hline & OSm15 & Rhodopseudomonas palustris $\mathrm{HaA} 2$ & $\mathrm{YP}_{-} 486641$ & $\begin{array}{l}\text { Esterase/lipase/ } \\
\text { thioesterase }\end{array}$ & 59.0 & IV \\
\hline \multirow[t]{4}{*}{ Betaproteobacteria } & OSm12 & Burkholderia gladioli ATCC 10248 & AAF59826 & Esterase estB & 57.7 & VIII \\
\hline & OSm13 & Burkholderia gladioli ATCC 10248 & AAF59826 & Esterase estB & 58.1 & VIII \\
\hline & OSm14 & Burkholderia thailandensis MSMB43 & ZP_02464527 & Putative lipoprotein & 35.4 & FE \\
\hline & OSm16 & Cupriavidus basilensis OR16 & ZP_-09622859 & $\beta$-lactamase & 81.4 & VIII \\
\hline \multirow[t]{3}{*}{ Gammaproteobacteria } & OSm17 & Pseudomonas synxantha BG33R & ZP_10142349 & Esterase estA & 100 & II \\
\hline & OSm18 & Pseudomonas synxantha BG33R & ZP_10142349 & Esterase estA & 97.3 & II \\
\hline & OSm19 & Xanthomonas albilineans GPE PC73 & YP_003374881 & $\begin{array}{l}\text { Carboxylesterase } \\
\text { bioH }\end{array}$ & 57.7 & V \\
\hline Deltaproteobacteria & OSm20 & Desulfococcus oleovorans $\mathrm{Hxd} 3$ & YP 001530546 & $\beta$-lactamase & 51.1 & VIII \\
\hline Actinobacteria & OSm21 & Streptomyces venezuelae ATCC 10712 & YP_ 006876070 & Esterase & 55.3 & VIII \\
\hline Armatimonadetes & OSm22 & Chthonomonas calidirosea T49 & YP_008088291 & Hydrolase & 26.5 & V \\
\hline \multirow[t]{3}{*}{ Acidobacteria } & OSm23 & $\begin{array}{l}\text { "Candidatus Koribacter versatilis" } \\
\text { Ellin345 }\end{array}$ & YP_589716 & $\beta$-lactamase & 43.8 & VIII \\
\hline & OSm24 & $\begin{array}{l}\text { "Candidatus Koribacter versatilis" } \\
\text { Ellin345 }\end{array}$ & YP_589716 & $\beta$-lactamase & 51.0 & VIII \\
\hline & OSm25 & $\begin{array}{l}\text { "Candidatus Solibacter usitatus" } \\
\text { Ellin6076 }\end{array}$ & YP_825272 & $\alpha / \beta$ hydrolase & 80.1 & V \\
\hline \multirow[t]{14}{*}{ Unidentified groups } & OSm26 & $\begin{array}{l}\text { uncultured bacterium } \\
\text { ACD_17C00118G0001 }\end{array}$ & EKE08525 & Hypothetical lipase & 50.0 & $\mathrm{NC}$ \\
\hline & OSm27 & uncultured bacterium pELP141 & AAS77238 & Lipase/esterase & 77.2 & IV \\
\hline & OSm28 & uncultured organism EstC23 & AFC77925 & Lipase/esterase & 74.8 & IV \\
\hline & OSm29 & uncultured bacterium pELP141 & AAS77238 & Lipase/esterase & 64.3 & IV \\
\hline & OSm30 & uncultured bacterium pELP141 & AAS77238 & Lipase/esterase & 77.8 & IV \\
\hline & OSm31 & uncultured bacterium pELP11B & AAS77236 & Lipase/esterase & 76.7 & IV \\
\hline & OSm32 & uncultured bacterium pELP141 & AAS77238 & Lipase/esterase & 79.5 & IV \\
\hline & OSm33 & uncultured organism EstC23 & AFC77925 & Lipase/esterase & 77.1 & IV \\
\hline & OSm34 & uncultured organism EstC23 & AFC77925 & Lipase/esterase & 75.9 & IV \\
\hline & OSm35 & uncultured bacterium FLS10 & ACL67845 & Lipolytic enzyme & 67.4 & IV \\
\hline & OSm36 & uncultured bacterium FeKT1 & ADH59410 & Feruloyl esterase & 45.1 & FE \\
\hline & OSm37 & uncultured bacterium pLE38 & AEM45146 & Lipase/esterase & 84.8 & IV \\
\hline & OSm38 & uncultured bacterium UVCL29 & ACF04196 & Lipase/esterase & 62.7 & IV \\
\hline & OSm39 & uncultured bacterium Est24 & AFB82697 & Lipase/esterase & 61.7 & IV \\
\hline
\end{tabular}

a The definition of the families (or groups) of lipolytic enzymes were according to previous studies $(2,8,23,35,39)$ : II, IV, V, and VIII, number of the family; FE, feruloyl esterase group; NC, novel cluster (shown in Fig. 1 and Fig. S1).

significant identity to the metagenomic clones obtained from soil $(28,36,38,46,53)$, marine sediment $(23,26)$, tidal flat sediment (34), and groundwater (62). These results strongly suggest that functional metagenomics combined with the oil-fed enrichment strategy contributed to uncover the phylogenetic diversity of lipolytic bacteria that had been overlooked by the cultivation-based screening technique.

All strains of culturable lipolytic isolates were phylogenetically assigned to three phyla and were further identified as seven genera: Burkholderia, Mitsuaria, and Pseudomonas of the phylum Proteobacteria; Bacillus and Lysinibacillus of the phylum Firmicutes; and Rhodococcus and Curtobacterium of the phylum Actinobacteria. To date, many lipolytic enzymes have been purified from members of the strains of Bacillus, Burkholderia, and Pseudomonas (19, 20, 24, 57). The closest relatives of the isolates classified into the other four genera were also shown to be lipolytic enzymeproducing bacteria $(1,3,4,14,29,54)$. Thus, all culturable 


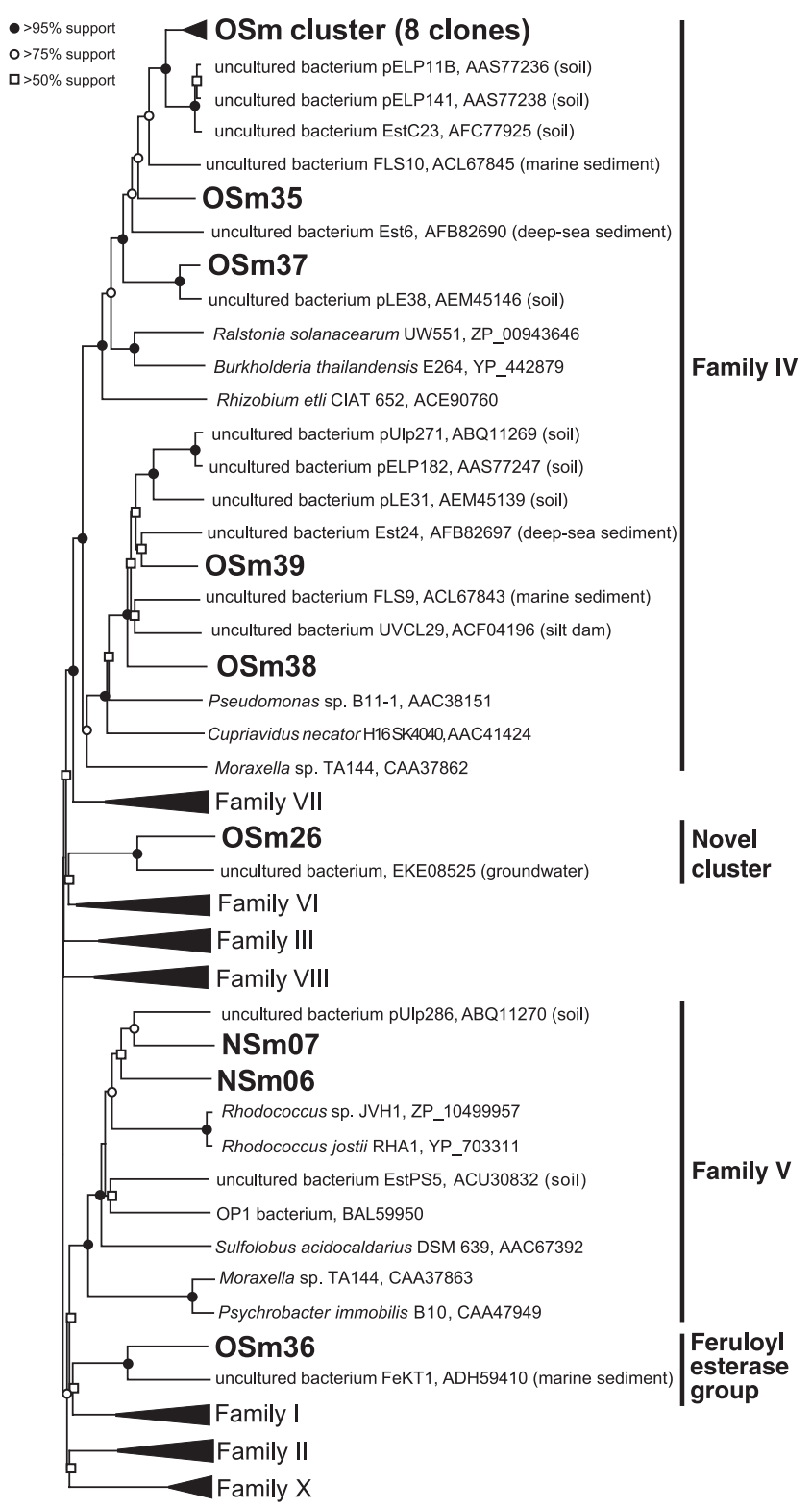

0.2

Fig. 1. Unrooted distance matrix tree of lipolytic enzymes obtained from non-enriched soil (NS) and oil-enriched soil (OS) metagenomic libraries. The phylogenetic tree was generated by the neighbor-joining method with MEGA 5.0 software. The classification of previously known lipolytic enzymes was based on Arpigny and Jaeger (2). Eight clones from OS (OSm27-34) were assembled into the OSm cluster. The source of lipolytic enzymes related to uncultured bacteria was shown in parenthesis. The topology of the tree was estimated by bootstrap analysis with 1,000 replicates. The bar indicates a 0.2 change per amino acid site.

lipolytic strains were phylogenetically associated with previously characterized lipolytic bacteria. Further studies are needed to compare the biochemical functions (e.g., activity and substrate specificity) of lipolytic enzymes obtained from the culturable isolates and metagenomic libraries.

We did not detect any lipolytic enzymes associated with the phylum Firmicutes from either the NS or OS metagenomic library in spite of their presence in the culturable lipolytic bacterial isolates. In addition, the 16S rRNA gene clones classified into this phylum were also undetectable

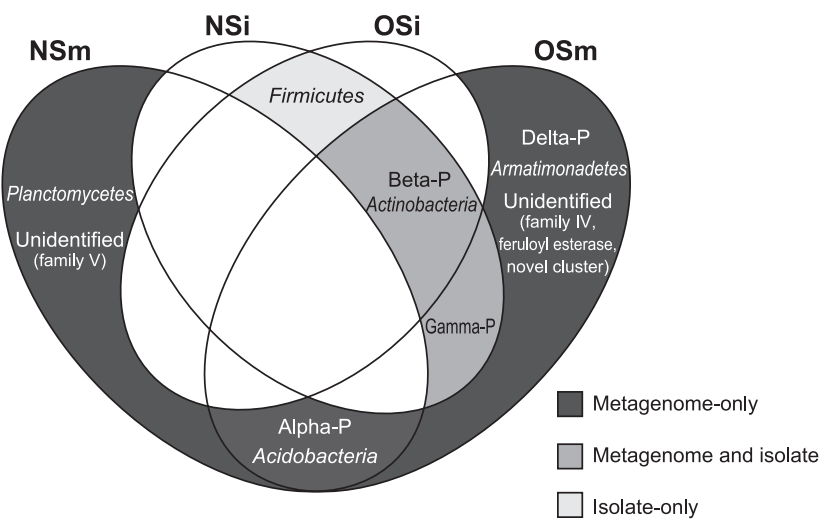

Fig. 2. Venn diagram of the phylogeny of lipolytic isolates and genes from non-enriched soil (NS) and oil-enriched soil (OS) metagenomic libraries. Abbreviations: NSi, culturable isolates from NS; OSi, culturable isolates from OS; NSm, metagenomic clones from NS; OSm, metagenomic clones from OS; Alpha-P, Alphaproteobacteria; Beta-P, Betaproteobacteria; Gamma-P, Gammaproteobacteria; Delta-P, Deltaproteobacteria.

(Table S1). These results indicate that culture conditions needed to isolate the lipolytic bacteria used in this study were suitable for the proliferation of Firmicutes, especially the genera Bacillus and Lysinibacillus. This may also indicate that the metagenomic screening procedure used in this study had potential biases against members of the phylum Firmicutes. To overcome this, there is still room for further improvements in the functional metagenomic approach. For example, the host strain may be an important factor in this respect. Previous metagenomic studies reported the use of Bacillus subtilis (5), Pseudomonas putida (43), Rhizobium leguminosarum (61), and Streptomyces lividans (11) as host strains as an alternative to E. coli to explore novel biocatalysts. Further studies using a functional metagenomic approach with multiple host strains may provide a deeper insight into the phylogenetic diversity of lipolytic microbes in forest soil ecosystems.

\section{Acknowledgements}

We are grateful to Norihiro Ozaki (Tokai University, Japan) for his technical assistance.

\section{References}

1. Amakata, D., Y. Matsuo, K. Shimono, J.K. Park, C.S. Yun, H. Matsuda, A. Yokota, and M. Kawamukai. 2005. Mitsuaria chitosanitabida gen. nov., sp. nov., an aerobic, chitosanase-producing member of the 'Betaproteobacteria'. Int. J. Syst. Evol. Microbiol. 55:1927-1932.

2. Arpigny, J.L., and K.E. Jaeger. 1999. Bacterial lipolytic enzymes: classification and properties. Biochem. J. 343:177-183.

3. Bassegoda, A., F.I.J. Pastor, and P. Diaz. 2012. Rhodococcus sp. strain CR-53 LipR, the first member of a new bacterial lipase family (family $\mathrm{X}$ ) displaying an unusual Y-type oxyanion hole, similar to the Candida antarctica lipase clan. Appl. Environ. Microbiol. 78:17241732.

4. Behrendt, U., A. Ulrich, P. Schumann, D. Naumann, and K. Suzuki. 2002. Diversity of grass-associated Microbacteriaceae isolated from the phyllosphere and litter layer after mulching the sward; polyphasic characterization of Subtercola pratensis sp. nov., Curtobacterium herbarum sp. nov. and Plantibacter flavus gen. nov., sp. nov. Int. J. Syst. Evol. Microbiol. 52:1441-1454. 
5. Biver, S., S. Steels, D. Portetelle, and M. Vandenbol. 2013. Bacillus subtilis as a tool for screening soil metagenomic libraries for antimicrobial activities. J. Microbiol. Biotechnol. 23:850-855.

6. Bunterngsook, B., P. Kanokratana, T. Thongaram, S. Tanapongpipat, T. Uengwetwanit, S. Rachdawong, T. Vichitsoonthonkul, and L. Eurwilaichitr. 2010. Identification and characterization of lipolytic enzymes from a peat-swamp forest soil metagenome. Biosci. Biotechnol. Biochem. 74:1848-1854.

7. Cardenas, F., M.S. de Castro, J.M. Sanchez-Montero, J.V. Sinisterra, M. Valmaseda, S.W. Elson, and E. Alvarez. 2001. Novel microbial lipases: catalytic activity in reactions in organic media. Enzyme Microb. Technol. 28:145-154.

8. Chow, J., F. Kovacic, Y.D. Antonia, et al. 2012. The metagenomederived enzymes LipS and LipT increase the diversity of known lipases. PLoS One. 7:e47665.

9. Chu, X.M., H.Z. He, C.Q. Guo, and B.L. Sun. 2008. Identification of two novel esterases from a marine metagenomic library derived from South China Sea. Appl. Microbiol. Biotechnol. 80:615-625.

10. Clarholm, M. 2002. Bacteria and protozoa as integral components of the forest ecosystem their role in creating a naturally varied soil fertility. Antonie Van Leeuwenhoek. 81:309-318.

11. Courtois, S., C.M. Cappellano, M. Ball, et al. 2003. Recombinant environmental libraries provide access to microbial diversity for drug discovery from natural products. Appl. Environ. Microbiol. 69:49-55.

12. Elend, C., C. Schmeisser, C. Leggewie, P. Babiak, J.D. Carballeira, H.L. Steele, J.L. Reymond, K.E. Jaeger, and W.R. Streit. 2006. Isolation and biochemical characterization of two novel metagenome-derived esterases. Appl. Environ. Microbiol. 72:3637-3645.

13. Entcheva, P., W. Liebl, A. Johann, T. Hartsch, and W.R. Streit. 2001. Direct cloning from enrichment cultures, a reliable strategy for isolation of complete operons and genes from microbial consortia. Appl. Environ. Microbiol. 67:89-99.

14. Falcocchio, S., C. Ruiz, F.I.J. Pastor, L. Saso, and P. Diaz. 2005. Identification of a carboxylesterase-producing Rhodococcus soil isolate. Can. J. Microbiol. 51:753-758.

15. Faoro, H., A. Glogauer, E.M. Souza, L.U. Rigo, L.M. Cruz, R.A. Monteiro, and F.O. Pedrosa. 2011. Identification of a new lipase family in the Brazilian Atlantic Forest soil metagenome. Environ. Microbiol. Rep. 3:750-755.

16. Faoro, H., A. Glogauer, G.H. Couto, E.M. de Souza, L.U. Rigo, L.M. Cruz, R.A. Monteiro, and F.D. Pedrosa. 2012. Characterization of a new Acidobacteria-derived moderately thermostable lipase from a Brazilian Atlantic Forest soil metagenome. FEMS Microbiol. Ecol. 81:386-394.

17. Fernandez-Arrojo, L., M.E. Guazzaroni, N. Lopez-Cortes, A. Beloqui, and M. Ferrer. 2010. Metagenomic era for biocatalyst identification. Curr. Opin. Biotechnol. 21:725-733.

18. Ferrer, M., O.V. Golyshina, T.N. Chernikova, A.N. Khachane, V.A.P.M. dos Santos, M.M. Yakimov, K.N. Timmis, and P.N. Golyshin. 2005. Microbial enzymes mined from the Urania deep-sea hypersaline anoxic basin. Chem. Biol. 12:895-904.

19. Gupta, R., N. Gupta, and P. Rathi. 2004. Bacterial lipases: an overview of production, purification and biochemical properties. Appl. Microbiol. Biotechnol. 64:763-781.

20. Hasan, F., A.A. Shah, and A. Hameed. 2006. Industrial applications of microbial lipases. Enzyme Microb. Technol. 39:235-251.

21. Henne, A., R.A. Schmitz, M. Bomeke, G. Gottschalk, and R. Daniel. 2000. Screening of environmental DNA libraries for the presence of genes conferring lipolytic activity on Escherichia coli. Appl. Environ. Microbiol. 66:3113-3116.

22. Houde, A., A. Kademi, and D. Leblanc. 2004. Lipases and their industrial applications-An overview. Appl. Biochem. Biotechnol. 118:155-170.

23. Hu, Y.F., C.Z. Fu, Y.P. Huang, et al. 2010. Novel lipolytic genes from the microbial metagenomic library of the South China Sea marine sediment. FEMS Microbiol. Ecol. 72:228-237.

24. Jaeger, K.E., and T. Eggert. 2002. Lipases for biotechnology. Curr. Opin. Biotechnol. 13:390-397.

25. Jaeger, K.E., and M.T. Reetz. 1998. Microbial lipases form versatile tools for biotechnology. Trends Biotechnol. 16:396-403.

26. Jiang, X.W., X.W. Xu, Y.Y. Huo, Y.H. Wu, X.F. Zhu, X.Q. Zhang, and M. Wu. 2012. Identification and characterization of novel esterases from a deep-sea sediment metagenome. Arch. Microbiol. 194:207-214.
27. Jimenez, D.J., J.S. Montana, D. Alvarez, and S. Baena. 2012. A novel cold active esterase derived from Colombian high Andean forest soil metagenome. World J. Microbiol. Biotechnol. 28:361-370.

28. Jin, P., X.L. Pei, P.F. Du, X.P. Yin, X.L. Xiong, H.L. Wu, X.L. Zhou, and Q.Y. Wang. 2012. Overexpression and characterization of a new organic solvent-tolerant esterase derived from soil metagenomic DNA. Bioresour. Technol. 116:234-240.

29. Kim, M.K., Y.J. Kim, H.B. Kim, S.Y. Kim, T.H. Yi, and D.C. Yang. 2008. Curtobacterium ginsengisoli sp. nov., isolated from soil of a ginseng field. Int. J. Syst. Evol. Microbiol. 58:2393-2397.

30. Kim, Y.J., G.S. Choi, S.B. Kim, G.S. Yoon, Y.S. Kim, and Y.W. Ryu. 2006. Screening and characterization of a novel esterase from a metagenomic library. Protein Expr. Purif. 45:315-323.

31. Kimura, N. 2006. Metagenomics: access to unculturable microbes in the environment. Microbes Environ. 21:201-215.

32. Kimura, N. 2010. Isolation and characterization of a 4-nitrotolueneoxidizing enzyme from activated sludge by a metagenomic approach. Microbes Environ. 25:133-139.

33. Knietsch, A., T. Waschkowitz, S. Bowien, A. Henne, and R. Daniel. 2003. Construction and screening of metagenomic libraries derived from enrichment cultures: Generation of a gene bank for genes conferring alcohol oxidoreductase activity on Escherichia coli. Appl. Environ. Microbiol. 69:1408-1416.

34. Lee, M.H., C.H. Lee, T.K. Oh, J.K. Song, and J.H. Yoon. 2006. Isolation and characterization of a novel lipase from a metagenomic library of tidal flat sediments: Evidence for a new family of bacterial lipases. Appl. Environ. Microbiol. 72:7406-7409.

35. Lee, M.H., K.S. Hong, S. Malhotra, J.H. Park, E.C. Hwang, H.K. Choi, Y.S. Kim, W.X. Tao, and S.W. Lee. 2010. A new esterase EstD2 isolated from plant rhizosphere soil metagenome. Appl. Microbiol. Biotechnol. 88:1125-1134.

36. Lee, S.W., K. Won, H.K. Lim, J.C. Kim, G.J. Choi, and K.Y. Cho. 2004. Screening for novel lipolytic enzymes from uncultured soil microorganisms. Appl. Microbiol. Biotechnol. 65:720-726.

37. Li, J.G., K.G. Zhang, and W.J. Han. 2010. Cloning and biochemical characterization of a novel lipolytic gene from activated sludge metagenome, and its gene product. Microb. Cell Fact. 9:83.

38. Nacke, H., C. Will, S. Herzog, B. Nowka, M. Engelhaupt, and R. Daniel. 2011. Identification of novel lipolytic genes and gene families by screening of metagenomic libraries derived from soil samples of the German Biodiversity Exploratories. FEMS Microbiol. Ecol. 78:188-201.

39. Narihiro, T., Y. Yamanaka, and A. Hiraishi. 2003. High culturability of bacteria in commercially available personal composters for fedbatch treatment of household biowaste. Microbes Environ. 18:94-99.

40. Narihiro, T., S. Takahashi, and A. Hiraishi. 2004. Activity and phylogenetic composition of proteolytic bacteria in mesophilic fed-batch garbage composters. Microbes Environ. 19:292-300.

41. Narihiro, T., and Y. Kamagata. 2013. Cultivating yet-to-be cultivated microbes: the challenge continues. Microbes Environ. 28:163-165.

42. Ogawa, J., and S. Shimizu. 1999. Microbial enzymes: new industrial applications from traditional screening methods. Trends Biotechnol. 17:13-21.

43. Ono, A., R. Miyazaki, M. Sota, Y. Ohtsubo, Y. Nagata, and M. Tsuda. 2007. Isolation and characterization of naphthalene-catabolic genes and plasmids from oil-contaminated soil by using two cultivationindependent approaches. Appl. Microbiol. Biotechnol. 74:501-510.

44. Puspita, I.D., Y. Kamagata, M. Tanaka, K. Asano, and C.H. Nakatsu. 2012. Are uncultivated bacteria really uncultivable? Microbes Environ. 27:356-366.

45. Ranjan, R., A. Grover, R.K. Kapardar, and R. Sharma. 2005. Isolation of novel lipolytic genes from uncultured bacteria of pond water. Biochem. Biophys. Res. Commun. 335:57-65.

46. Rashamuse, K., T. Ronneburg, F. Hennessy, D. Visser, E. van Heerden, L. Piater, D. Litthauer, C. Moller, and D. Brady. 2009. Discovery of a novel carboxylesterase through functional screening of a pre-enriched environmental library. J. Appl. Microbiol. 106:15321539.

47. Rhee, J.K., D.G. Ahn, Y.G. Kim, and J.W. Oh. 2005. New thermophilic and thermostable esterase with sequence similarity to the hormone-sensitive lipase family, cloned from a metagenomic library. Appl. Environ. Microbiol. 71:817-825. 
48. Rondon, M.R., P.R. August, A.D. Bettermann, et al. 2000. Cloning the soil metagenome: a strategy for accessing the genetic and functional diversity of uncultured microorganisms. Appl. Environ. Microbiol. 66:2541-2547.

49. Saisuburamaniyan, N., L. Krithika, K.P. Dileena, S. Sivasubramanian, and R. Puvanakrishnan. 2004. Lipase assay in soils by copper soap colorimetry. Anal. Biochem. 330:70-73.

50. Saitou, N., and M. Nei. 1987. The neighbor-joining method: a new method for reconstructing phylogenetic trees. Mol. Biol. Evol. 4:406-425.

51. Sayers, E.W., T. Barrett, D.A. Benson, et al. 2011. Database resources of the National Center for Biotechnology Information. Nucleic Acids Res. 39:D38-D51.

52. Shimizu, S., J. Ogawa, M. Kataoka, and M. Kobayashi. 1997. Screening of novel microbial enzymes for the production of biologically and chemically useful compounds. Adv. Biochem. Eng. Biotechnol. 58:45-87.

53. Sik, H.K., H.K. Lim, E.A. Chung, E.J. Park, M.T. Lee, J.C. Kim, G.J. Chov, K.Y. Cho, and S.W. Lee. 2007. Selection and characterization of forest soil metagenome genes encoding lipolytic enzymes. J. Microbiol. Biotechnol. 17:1655-1660.

54. Sulong, M.R., R.N.Z.R. Abd Rahnian, A.B. Salleh, and M. Basri. 2006. A novel organic solvent tolerant lipase from Bacillus sphaericus 205y: Extracellular expression of a novel OST-lipase gene. Protein Expr. Purif. 49:190-195.

55. Tamura, K., D. Peterson, N. Peterson, G. Stecher, M. Nei, and S. Kumar. 2011. MEGA5: Molecular evolutionary genetics analysis using maximum likelihood, evolutionary distance, and maximum parsimony methods. Mol. Biol. Evol. 28:2731-2739.
56. Taupp, M., K. Mewis, and S.J. Hallam. 2011. The art and design of functional metagenomic screens. Curr. Opin. Biotechnol. 22:465-472.

57. Treichel, H., D. de Oliveira, M.A. Mazutti, M. Di Luccio, and J.V. Oliveira. 2010. A review on microbial lipases production. Food Bioprocess Technol. 3:182-196.

58. van der Heijden, M.G.A., R.D. Bardgett, and N.M. van Straalen. 2008. The unseen majority: soil microbes as drivers of plant diversity and productivity in terrestrial ecosystems. Ecol. Lett. 11:296-310.

59. Voget, S., C. Leggewie, A. Uesbeck, C. Raasch, K.E. Jaeger, and W.R. Streit. 2003. Prospecting for novel biocatalysts in a soil metagenome. Appl. Environ. Microbiol. 69:6235-6242.

60. Wei, P., L.P. Bai, W.G. Song, and G.P. Hao. 2009. Characterization of two soil metagenome-derived lipases with high specificity for p-nitrophenyl palmitate. Arch. Microbiol. 191:233-240.

61. Wexler, M., P.L. Bond, D.J. Richardson, and A.W.B. Johnston. 2005. A wide host-range metagenomic library from a waste water treatment plant yields a novel alcohol/aldehyde dehydrogenase. Environ. Microbiol. 7:1917-1926.

62. Wrighton, K.C., B.C. Thomas, I. Sharon, et al. 2012. Fermentation, hydrogen, and sulfur metabolism in multiple uncultivated bacterial phyla. Science 337:1661-1665.

63. Yoshida, N., Y. Fujii, and A. Hiraishi. 2006. A modified cyanoditolyl tetrazolium reduction method for differential detection of metabolically active Gram-positive and Gram-negative bacteria. Microbes Environ. 21:272-277.

64. Zuo, K.J., L.D. Zhang, H.Y. Yao, and J. Wang. 2010. Isolation and functional expression of a novel lipase gene isolated directly from oil-contaminated soil. Acta Biochim. Pol. 57:305-311. 